УДК 94 (567) : 355.321 «1958/1973»

DOI: https://doi.org/10.33782/eminak2019.4(28).352

\title{
РАЗВИТИЕ ВОЕННО-МОРСКИХ СИЛ ИРАКА В 1958-1973 ГОДАХ И КУВЕЙТСКИЕ КРИЗИСЫ
}

\author{
Андрей Поспелов \\ Одесская академия непрерывного образования (Одесса, Украина) \\ e-mail: andreas.pospelov@gmail.com \\ ORCID: https://orcid.org/0000-0002-8789-6393
}

Стаття розкриває особливості розбудови та розвитку військово-морських сил Іраку від Липневої революції 1958 р. до кінця другої кувейтської кризи у лютому-березні 1973 р. Наведено відомості про всі бойові кораблі та катери, поставлені до Іраку у зазначений період, коротко охарактеризована діяльність деяких його командувачів та описані дії ВМС Іраку в ході першої та другої кувейтських криз 1961 і 1973 років.

Ключові слова: Іракська республіка, військово-морські сили, кувейтський криза, бойові катери, дивізіон

История военно-морских сил Ирака в отечественной и зарубежной историографии практически не представлена. Не охарактеризовано и участие иракских моряков в военно-политических кризисах, имевших место до Ирано-иракской войны 1980-1988 гг. Работы западных авторов активизируют внимание читателя к ВМС Ирака лишь с начала войны с Ираном, а подробно анализируют его лишь применительно к Кризису в Персидском заливе 1990-1991 гг., или хронологически к Третьему Кувейтскому кризису.

Немногочисленные публикации украинского автора А.С. Поспелова рассматривали историю ВМС Ирака до 1958 г. и в период 1977-1991 гг. ${ }^{1}$ В цикле статей российского автора Р. Кузнецова² период 1958-1973 гг. освещается крайне скупо и применительно к материальной составляющей ВМС Ирака.

Ввиду этого, целью статьи является раскрытие аспектов развития ВМС Ирака в период 1958-1973 гг. В этот период происходит становления ВМС Ирака, с помощью СССР, как современного флота, который хронологически охватывает первые два кувейтских кризиса 1961 и 1973 гг. соответственно. Анализ указанных аспектов является задачей нашей публикации.

В ночь с 13 на 14 июля 1958 г. группа «свободных офицеров» вооружённых сил Ирака во главе с бригадиром Абдель-Керимом Касемом совершила военный переворот, в результате которого был свергнут король Фейсал II и ушло в небытие проамериканское правительство премьер-министра Нури Саида. Это событие вошло в историю как Июльская революция. По сути, так оно и было, ибо военный переворот носил, прежде всего, антифеодальный и антиимпериалистический характер и был

\footnotetext{
1 Поспелов А.С. ВМС Ирака от получения независимости до Революции 1958 г. // Полілог. Збірник наукових праць. 2014. Вип. 1. С. 118-108; Поспєлов А.С. Розвиток військово-морських сил Іракської Республіки у 1977-1991 pp. // Україна наукова. Матеріали II Всеукраїнської наукової конференції. Київ, 21-23.12.2006. С. 28-31.

2 Кузнецов Р. История ВМФ Ирака. Ч. 1: Начало (1958-1980 гг.) // Военное обозрение. 2014. 7 октября. URL: http://topwar.ru/59696-istoriya-vmf-iraka-chast-1-nachalo-1958-1980-gg.html
} 
благодушно принят широкими массами населения Ирака.

По результатам Июльской революции Ирак был провозглашён республикой. А на следующий день новое иракское руководство объявило о выходе страны из Багдадского пакта, заключённого в 1955 г. под эгидой США и носившего явный антисоветский характер. Официально Иракская республика покинула эту организацию 24 марта 1959 г. Расположенные же на территории Ирака британские военные контингенты получили указание покинуть её3. Всё это открыло для Ирака возможность плодотворного сотрудничества со многими странами, и в особенности с Советским Союзом, в том числе и в области военно-морского строительства.

Стимулом для этого стало то, что Великобритания отказалась признать новый статус Ирака. Сосредоточив у его берегов мощную эскадру и перебросив в Кувейт подразделения своих сухопутных войск и ВВС, британские штабисты стали готовить интервенцию против молодой республики. И хотя правящая в Кувейте династия ас-Сабахов и население этой британской колонии не позволило осуществить британцам вторжение в Ирак ${ }^{4}$, стало понятно, что новообразованной республике следует иметь мощный военно-морской флот, ориентированный, прежде всего, на борьбу с надводными кораблями противника у своего побережья.

Исходя из этих соображений, уже в конце 1958 г. был заключён первый контракт с Советским Союзом на приобретение 10 малых торпедных катеров типа «Комсомолец» (проект 123К5) и 12 больших торпедных катеров типа «Большевик» (проект 183). По различным причинам первые на берега Персидского залива так и не попали, а вот вся партия торпедных катеров типа «Большевик» поступила в Ирак с января 1959 по январь 1961 г.

Все иракские «Большевики» получили бортовые номера 217-222 и долгое время использовались исключительно на реке Шатт-эль-Араб. Причём использовались группами (дивизионами) по 6 катеров, из которых один дивизион активный, а иной - резервный. Бортовые номера наносились лишь на катера активного дивизиона, что породило настоящую путаницу в западных справочниках, в которых с 1975 по 1982 годы фигурировало то 6, то 8, то 12 катеров проекта 183 в составе ВМС Ирака6.

В мае 1961 г. в Ирак из СССР прибыли 3 противолодочных (патрульных) катера проекта 201, получившие бортовые номера 310, 311 и 312, но не названия. Вместе с поставленными из СССР кораблями, для обучения иракских моряков были направлены и советские специалисты

Интересно, что западные аналитики обнаружили эти, весьма совершенные для своего времени, противолодочные корабли прибрежного действия в составе ВМС Ирака лишь год спустя. И не удивительно, ведь командование ВМС Ирака предполагало их использовать исключительно как пограничные и патрульные, причём не только на реке Шатт-эль-Араб, но и в северной части Персидского залива, куда до

\footnotetext{
3 Революция в Ираке / Под ред. Б.Н. Антоновича. Москва, 1959. 37 с.

4 Грант Н. Конфликты 20-го века. Москва, 1992. С. 305; Малые торпедные катера проектов 123бис и 123К, шифр «Комсомолец». URL: http://russianships.info/katera/123.htm; Рогозин А. Персидская эпопея советского флота // Советский флот в войнах и конфликтах «холодной войны». URL: http://alerozin.narod.ru/pers.htm

5 Большие торпедные катера, пограничные сторожевые корабли Проект 183, шифр «Большевик». URL: http://russianships.info/katera/183.htm; Torpedoe Boats Type P-6. URL: http://iraqimilitary.org/forums/viewtopic.php?f=8\&t=145

6 The Iraqi Submarine Chaser type SO-1. URL: http://iraqimilitary.org/forums/viewtopic.php?f=8\&t=146
} 
1973 г. выходили они весьма редко. При этом, 252-мм пятиствольные реактивные бомбомётные установки РБУ-1200 этих катеров изначально предполагалось использовать не для поражения потенциальных иранских подводных лодок, а для обстрела спорных участков побережья на территории шахского Ирана7.

Одновременно с торпедными и противолодочными катерами в Ирак пришли и первые вспомогательные единицы: 2 водолазных катера проекта 522 и 1 пожарный катер проекта 364. Впрочем, по своему прямому назначению они не использовались и вооружённые пулемётами эксплуатировались в качестве патрульных.

Процесс обучения иракских моряков был неожиданно прерван так называемым «первым кувейтским кризисом». 19 июня 1961 г. Великобритания предоставила эмирату Кувейт независимость, которую иракское правительство признавать отказалось, заявив 25 июня претензии на территорию новоиспечённого государства. По словам лидера Ирака, его страна имеет «наследственные права» на Кувейт, поскольку его территория в период существования Османской империи была частью Багдадского вилайета. При этом шейх Кувейта всегда являлся лишь представителем губернатора Басры ${ }^{8}$.

В подтверждение этих слов, 28 июня иракское правительство направило специальный меморандум в Лигу Арабских Стран, а на границе с новообразованным государством стали концентрироваться иракские войска - 4-я танковая дивизия и 15-я отдельная пехотная бригада. Кувейт же, в свою очередь, обратился за помощью к ООН и к бывшей метрополии ${ }^{9}$.

Уже 1 июля 1961 г. с десантного вертолётоносца «Булварк» (HMS Bulvark) высадились в Кувейте первые 750 британских морских пехотинцев из состава 42-й группы коммандос ${ }^{10}$. До конца месяца Великобритания сосредоточила в Кувейте и у его побережья 11 боевых кораблей, включая авианосец «Викториес» (HMS Victories), 200 боевых самолётов и 7000 солдат и офицеров сухопутных войск.

А к 10 октября, на смену британским солдатам, прибыли контингенты из Саудовской Аравии, Сирии, Иордании, Судана и Объединённой Арабской Республики (Египта), которые находились там до конца января 1963 г. (британские войска под давлением международного сообщества полностью покинули территорию Кувейта в августе 1962 г.).

«Первый кувейтский кризис» продолжался практически полтора года и закончился согласием Ирака признать Кувейт (в феврале 1964 г. обе страны обменялись посольствами) ${ }^{11}$. Но, как и в мае 1941 г., катера ВМС Ирака опять не покидали своей базы, а потому в противостоянии вокруг Кувейта новейшая советская техника участия не принимала. Хотя именно в этом противостоянии иракские ВМС могли сыграть довольно приметную роль по принципу «fleet-in-being» (флот действует одним лишь фактом своего существования), элементарно выйдя в море. Конечно, против британской группировки из авианосца, вертолётоносца, 4 эсминцев и 10 фрегатов, ВМС Ирака, состоящие из 12 торпедных, 3 сторожевых (противолодочных) катеров и десятка иных менее боеспособных единиц, сделать по определению ничего не мо-

\footnotetext{
7 Павлов А. Боевые корабли СССР и России 1945-1995. Якутск, 1995. С. 201.

8 Кувейтский кризис 1961 года. URL: http://antinormanist.livejournal.com/213587.html

9 За рубежом. 1961. № 27. С. 2.

10 Политика Англии на Ближнем и Среднем Востоке, 1945-1965 / Под. ред. Г.Л. Бондаревского. Москва, 1966. С. 293-297.

11 Ibid. C. 300.
} 
гли. Однако, создать давление на британские корабли, вынудив их держаться от побережья как можно дальше, иракские моряки были вполне способны.

Интересно отметить, что в период «первого кувейтского кризиса» все арабские страны выступили против иракских притязаний на новоиспечённое монархическое государство. Кроме того, этот кризис показал, что Великобритания уже не всесильна и, следуя новым международным нормам, склонна передавать решения арабских проблем в руки самих арабских стран и их организаций. Как результат, лидеры Ирака сделали следующие выводы:

1. В дальнейшем все арабские проблемы будут решаться самими арабскими странами и организациями (во всяком случае, намечалась такая тенденция), поэтому следует искать здесь дипломатические «лазейки» или занимать лидирующие позиции.

2. Неспособность Ирака принять решительные меры к Кувейту и его союзникам была обусловлена его военной слабостью. Именно поэтому следует наращивать свой военный потенциал до уровня региональной супердержавы. Фактически, должна возобладать старая истина, бытующая в арабском мире - «прав тот, кто силён».

Впрочем, необходимые выводы были сделаны быстро. Ещё до «первого кувейтского кризиса», в 1958 г., Абдель-Керим Касем основал новую военно-морскую базу на побережье небольшого городка Умм Каср (Umm Qasr). Правда, в период первого противостояния с Кувейтом, этот стратегически важный объект был объявлен портом, и иракская сторона аргументировала свои претензии к Кувейту, в том числе, и необходимостью входа/выхода из него океанских транспортных судов. Впрочем, после «первого кувейтского кризиса» строительство военно-морской базы в Умм Касре, в первую очередь, и порта морского во вторую, шло форсированными темпами с помощью специалистов из ФРГ и Швеции на деньги Ливана и продолжалось вплоть до начала 1973 г. С помощью же советских специалистов, иракцы одновременно быстро стали осваивать новую для себя военно-морскую технику.

Уже в конце 1963 г. 2 дивизиона торпедных и 1 дивизион противолодочных катеров достигли приемлемого уровня боеготовности. Но, развив береговую инфраструктуру и значительно подтянув выучку иракских военных моряков, чему, в немалой степени, способствовали активные действия командующего военно-морскими силами и береговой обороной Иракской Республики, бригадира Мохаммеда Рауфа, разыграть вновь кувейтскую карту, Абдель-Керим Касем не смог. 8 февраля 1963 г., в результате очередного военного переворота, он и два его сподвижника были расстреляны в багдадской телестудии. А к власти надолго пришла иракская вариация партии Арабского Социалистического Возрождения (БААС), во главе с полковником Абдель Саламом Арефом.

Несмотря на смену власти, ВМС Ирака продолжали строиться по принятой ещё в 1958 г. программе - полной ориентации на Советский Союз при остаточном финансировании этого вида вооружённых сил страны. Так, в первой половине 1960-х гг. Ирак озаботился созданием и минно-тральных сил. С Москвой велись переговоры на поставку 4 рейдовых тральщиков проекта $255 К$ и, по некоторым данным, в 1967 г. они пришли в Ирак ${ }^{12}$.

Несколько ранее, в 1966 г., в ВМС Ирака из состава ВМФ СССР было передано 3 рейдовых буксира проекта 376, которые тут же были вооружены спаренными 25-мм

12 Кузнецов Р. История ВМФ Ирака... 
и 14,5-мм установками и включены в состав дивизиона патрульных катеров. Эти катера получили бортовые номера 110-112.

В марте 1969 г. Ирак приобрёл у СССР 2 морских тральщика проекта 254-465 «Аль Ярмук» (Al Yarmouk) и 467 «Аль Кадиссия» (Al Kadisia) ${ }^{13}$, что позволило сформировать 5-й дивизион (4-й состоял из номерных канонерских лодок и 2 советских патрульных катеров проекта 368, поставленных в конце 1968 г. (б/н 223 и 224).

К этому времени несколько изменилось и внутриполитическое положение Ирака. 17-30 июля 1968 г. правительство генерала Арефа было свергнуто очередным военным переворотом, получившим в Ираке название «Вторая Июньская революция» или «Баасистская революция» (по названию Партии БААС, пришедшей тогда к власти), в результате чего страну возглавил А́хмед Ха́сан аль-Ба́кр.

Во внешней политике Ирака, по большому счёту, мало что изменилось. Разве что усилилась её антиизраильская направленность. Но подобные процессы происходили тогда во всех арабских странах, стремящихся смыть позор военного и морального поражения Шестидневной войны 1967 г. Другое дело, что с момента «Баасистской революции», на первые позиции в Иракской Республике в области военного строительства стал выдвигаться её будущий президент - Саддам Хусейн альТикрити, у которого были свои виды на Ирак как на региональную супердержаву. И военно-морским силам в этих планах отводилась отнюдь не вспомогательная роль.

Именно С. Хусейн стал в начале 1970-х гг. отвечать за сотрудничество с Советским Союзом. Уже в феврале 1972 г. он совершил официальный визит в Москву, где ознакомился с новейшими образцами советской военной техники, предлагаемой СССР для поставок на экспорт. По результатам переговоров с Председателем Совета Министров СССР Алексеем Косыгиным, 9 апреля 1972 г. был заключён Советскоиракский договор о дружбе и сотрудничестве. В числе прочего он предусматривал и значительное расширение советско-иракского сотрудничества в военной сфере.

Как результат, в июле-декабре 1972 г. ВМС Ирака получили новое качество: в СССР были заказаны 3 ракетных катера проекта 183-Р. Однако правительство Ирака быстро спохватилось и решило, что следует закупить более совершенные катера. В итоге сделка трансформировалась в закупку Ираком 3-х ракетных катеров, проекта 205 (Osa I, тип «Хазирани» по названию головного в иракской серии - R-15 «Хазирани» (Hazirani), R-6 «Канун Атх-Тхани» (Khanun ath-Thani), R-7 «Нисан» (Nisan)) ${ }^{14}$.

Эти катера быстро обрели популярность в иракском военном флоте. Их закупка не только резко подняла моральный дух иракских военных моряков, но и авторитет BMC страны в целом: 3 простых 210-тонных катера неожиданно выявились сильнейшими кораблями Персидского залива, ведь тогда ни один другой флот региона ничем аналогичным не располагал.

Иракской стороной ставился даже (причём неоднократно - минимум в 1973, 1974 и в 1983 гг.) вопрос о дополнительных закупках этих катеров или об организации их лицензионного производства на судостроительном заводе в Басре. Но по причинам слабой технологической базы Ирака и из-за нежелания советской стороны передавать иракцам ряд секретных технологий (например, в 1970-х гг. - противокорабельные ракеты П-15 и оборудование для их изготовления и применения),

13 Minesweepers and Minelayers of the Iraqi Navy. URL: http://iraqimilitary.org/forums/viewtopic.php?f=8\&t=101

${ }_{14}$ Komar class missile boats. URL: http://iraqimilitary.org/forums/viewtopic.php?f=8\&t=160; OSA Class Missile Boats. URL: http://iraqimilitary.org/forums/viewtopic.php?f=8\&t=99 
эти планы оказались нереализованными.

Однако в западной историографии, а вслед за ней и в ряде работ российских и белорусских исследователей, постоянно утверждается, что «ос первых» в Ирак было поставлено не 3, а 6 единиц. Видимо, информация о переговорах, касательно закупки второй партии из 3-х единиц стала известна западным аналитикам, которые восприняли её как свершившийся факт. Равно как и наличие в составе ВМС страны 3-х малых ракетных катеров проекта 183-P (Komar). Не избежал этого и такой авторитетнейший специалист по советскому военно-морскому флоту как Норман Полмар (Norman Polmar), указавший соответствующие цифры в своём знаменитом на Западе комплексном исследовании по советскому военно-морскому флоту15.

К началу 1973 г. ВМС Ирака достигли численности в 2500 человек, причём, подавляющая часть офицерского состава была обучена советскими инструкторами (всего с конца 1969 по конец 1991 гг. только военно-морские училища и академии СССР закончили 192 иракских офицера) ${ }^{16}$. Радиус использования ВМС Ирака расширился на всю северную часть Персидского залива, но функции их продолжали оставаться неизменными - береговая охрана и патрулирование водного района.

Советско-иракское сотрудничество развивалось и в иной плоскости. Так, в соответствии с Распоряжением Совета Министров СССР № 293-рс от 5 февраля 1969 г., в течении 1969-1973 гг. в порту Умм-Каср советскими специалистами была создана мастерская по ремонту военно-морской техники. Услугами этой мастерской могли пользоваться как иракские, так и советские боевые корабли, а также вспомогательные суда при заходах в иракские порты для отдыха и пополнения запасов. В 1973 г. 13 советских боевых кораблей посетили порты Ирака, в 1974 - 18, а за пять месяцев 1975 г. уже 7. Такая интенсивность дала повод президенту США Дж. Форду 28 августа 1974 г. на пресс-конференции заявить о наличии советской военноморской базы в Умм Касре, что не соответствовало действительности ${ }^{17}$.

Вместе с тем, в начале 1970-х гг. появляются планы развития Ирака как морской державы. Правительство республики взяло курс на создание собственного транспортного, танкерного и океанского рыболовного флота. С рядом государств Запада (ФРГ, Франция, Великобритания, Швеция, Япония) были заключены соглашения на поставку различного оборудования и строительство гражданских судов ${ }^{18}$. Не остался обделённым и Советский Союз, где на Херсонском судостроительном заводе в 1971-72 гг. по заказу Ирака построили 4 сухогруза - «Багдад», «Басра», «Вавилон» и «Синдбад» ${ }^{19}$.

Интенсивно велась и боевая подготовка ВМС Ирака. Это стало заслугой их нового командующего - гражданина Сирии (данный факт есть доказательством стремления Багдада и Дамаска в 1970-1979 гг. создать единое государство) контр-адмирала Али аль-Даири Абу Фираса. Именно он стал первым иракским офицером, официально получившим классическое военно-морское адмиральское звание, хотя по традиции, у морских офицеров ещё долгое время сохранялись обычные сухопутные зва-

\footnotetext{
15 Polmar N. Guide to the Soviet Navy. London-Sydney, 1986. P. 513.

16 Россия (СССР) в локальных войнах и военных конфликтах второй половины XX века / Под ред. В.А. Золотарёва. Москва, 2000. С. 212.

17 Рогозин А. Персидская эпопея советского флота // Советский флот в войнах и конфликтах «холодной войны». URL: http://alerozin.narod.ru/pers.htm

${ }^{18}$ List of all Iraqi registered ships. URL: http://iraqimilitary.org/forums/viewtopic.php?f=8\&t=162

19 Рогозин А. Персидская эпопея...
} 
ния. Да и сами ВМС Ирака организационно считались 7-й бригадой Армии Ирака.

Аль-Даири сделал попытку не только укрепить и усовершенствовать военноморские силы и береговую оборону Иракской республики, но, что самое главное, создать в сухопутном, по сути, иракском обществе настоящие морские традиции и развить классическую морскую культуру. С этой целью, ежегодно с 1971 г. в Басре и иных приморских (приречных) городах Ирака проводились различные морские фестивали, собиравшие огромное количество молодых людей. А раз так, то и численность ВМС Ирака стала постепенно расти, перешагнув уже в 1975 г. рубеж в 3000 человек ${ }^{20}$.

Новую же базу в Умм Касре, строительство которой официально завершилось в 1972 г., иракские военные моряки осваивали крайне медленно. В отличии от Басры, её акватория непосредственно выходила к Персидскому заливу. Однако подходы к ней были возможны лишь по фарватерам, которые контролировал Кувейт. Потому, размещать в новой ВМБ основной корабельный состав ВМС Ирака, было рискованHо.

Выходом из этой неприятной ситуации, по мнению багдадских лидеров, стало б принятие в аренду кувейтских островов Бубиян и Варба, на первом из которых планировалось построить новую ВМБ. Переговоры по этому вопросу между правительствами двух стран шли с начала 1970-х гг., однако позиция Кувейта оказалась неуступчивой. При этом обе страны, согласно плану «Ярмук», готовились вместе с Египтом, Сирией и другими арабскими странами начать войну с Израилем за возвращение потерянных в 1967 г. арабских территорий. Но в конце февраля 1973 г., ирако-кувейтские переговоры окончательно зашли в тупик и отношения между двумя странами резко ухудшились. А раз так, то в Багдаде решили острова просто захватить.

20 марта 1973 г. (ровно за 30 лет до начала Второй иракской войны) иракские войска захватили пограничный кувейтский пост Самта и высадились на островах Бубиян и Варба. Так начался «второй кувейтский кризис». Переброска пехотных подразделений и техники осуществляли суда торгового флота Ирака, тогда как боевые катера ВМС страны сопровождали и охраняли их. Первая в истории боевая операция BMC Ирака прошла быстро и без жертв, не в последнюю очередь из-за отсутствия сопротивления со стороны кувейтцев. Да и что они могли противопоставить иракским BMC, которые не только превосходили ВМС Кувейта, насчитывавшим всего 8 патрульных катеров типа «Аль-Салеми» (20 узлов скорости и один крупнокалиберный пулемёт) в численности и качестве, но и переиграли их тактически. Первый и последний раз в истории Ирака в море был выведен практически весь военноморской флот страны!

Иракский ордер строился по всем правилам: авангард - ракетные катера и тральщики, центр - транспорты под прикрытием торпедных катеров и арьергард (он же резерв) - 3 противолодочных катера. Атаковать его могла с надеждой на успех лишь авиация ВВС Кувейта. Но, ни один самолёт с аэродромов этого маленького эмирата не взлетел - сказывался как некомплект и слабая подготовка лётного состава, так и необходимость придержать современные истребители для готовящейся

\footnotetext{
20 Пенкин Е. Иракская республика и её вооружённые силы. Москва, 1977. С. 77; Юрченко В.П. Военная политика и военное строительство в странах Арабского Востока (конец XX - начало XXI века). Ч. 1. Москва, 2007. С. 98.
} 
войны с Израилем 21.

Иракское командование сразу же заявило, что пошло на операцию по захвату Бубияна и Варбы с целью защиты своего только что построенного порта Умм Каср. В свою очередь, правительство Кувейта обратилось в Лигу Арабских Государств за помощью. Военную помощь маленькой стране сразу же предложили Иран, Иордания и Саудовская Аравия 22. Последняя ввела на территорию Кувейта 15000 своих солдат. Противостоять такой коалиции - фактически вести войну на 3 фронта, Иракская Республика не имела возможности. Поэтому 25 марта 1973 г. правительство Ирака согласилось на переговоры с Кувейтом при посредничестве Египта и Сирии, а в конце апреля того же года, иракские войска оставили кувейтские острова 23.

Очередной, второй по счёту конфликт с Кувейтом для Ирака закончился безрезультатно, но его итоги для ВМС страны выявились позитивными. Во-первых, ВМС Ирака показали, что могут воевать по классическому принципу «fleet-in-being» (флот действует одним лишь фактом своего существования - чего не случилось летом 1961 г.). Во-вторых, основная масса корабельного состава ВМС Ирака была переведена в Умм Каср, а правительство Кувейта приняло на себя обязательства не создавать препятствий иракским кораблям и судам в фарватерной зоне. После этого, с апреля 1973 г. Умм Каср стал главной ВМБ ВМС Ирака. Но и в-третьих, и это следует считать главнейшим результатом противостояния с Кувейтом в начале 1973 г. - военно-политическое руководство Ирака пришло к выводу о необходимости создания так называемого «большого флота». Амбициозная программа по его строительству велась в 1977-1990 гг., но так и не была доведена до конца.

\section{REFERENCES}

Antonovich, B.N. (Ed.) (1959). Revoliutsyia v Irake [The revolution in Iraq]. Moskva: Izdatelstvo zarubezhnoi literatury [in Russian].

Arabo-izrailskiie voiny. Arabskiy vzgliad (2008). [Arab-Israel war. Arabic look]. Moskva: Yauza [in Russian].

Bondarevskiy, G.L. (Ed.) (1966). Politika Anglii na Blizhnem i Srednem Vostoke 1945-1965 [Politics of England in the Near and Middle East 1945-1965]. Moskva: Nauka [in Russian].

Grant, Neyl (1992). Konflikty 20-go veka [Conflicts of the 20th century]. Moskva: Fizkultura i sport [in Russian].

Kuznetsov, R. (2014). Istoriia VMF Iraka. Chast 1. Nachalo (1958-1980 gg.) [History of the Navy of Iraq. Part 1. The Beginning (1958-1980)]. Voennoe obozrenie, October 7. Retrieved from: http://topwar.ru/59696-istoriya-vmf-iraka-chast-1-nachalo-1958-1980-gg.html

Pavlov, A. (1995). Boievyie korabli SSSR i Rossii, 1945-1995 [Warships of the USSR and Russia, 19451995]. Yakutsk [in Russian].

Penkin, Ye. (1977). Irakskaia respublika i yeio vooruzhonnyie sily [Iraq Republic and its armed forces]. Moskva: Nauka [in Russian].

Polmar, N. (1986). Guide to the Soviet Navy. London-Sydney: Arms and armour press [in English].

Pospielov, A.S. (2006). Rozvytok viiskovo-morskykh syl Irakskoi Respubliky u 1977-1991 rr. [Development of the Naval Forces of the Iraqi Republic in 1977-1991]. In: Ukraina naukova. Materialy II vseukrainskoi naukovoi konferentsii (pp. 28-31). Kyiv [in Ukranian].

Pospielov, A.S. (2014). VMS Iraka ot poluchenia nezavisimosti do revolutsii 1958 goda [Iraqi Navy from independence to the 1958 Revolution]. Polilog: Zbirnyk naukovykh prats, 1, 118-108 [in Russian].

Rogozin, A. (2010). Persidskaia epopeia sovetskogo flota [Persian saga of the Soviet fleet]. In Sovetskii flot v voinakh $i$ konfliktakh «kholodnoi voiny». Retrieved from: http://alerozin.narod.ru/pers.htm

\footnotetext{
21 Арабо-израильские войны. Арабский взгляд. Москва, 2008. С. 84-87.

22 Аргументы и факты, 1990. № 32. С. 1.

23 Walid E. Moubarak. The Kuwait Fund in the context of Arab and Third word politics // The Middle East Journal. 1977. № 4. P. 474.
} 
Yurchenko, V.P. (2007). Voiennaia politika i voiennoie stroitelstvo $v$ stranakh Arabskogo Vostoka (konets $X X$ - nachalo XXI veka) [Military policy and military construction in the countries of the Arab East (late XX - early XXI centuries)]. Moskva: Institut Blizhnego Vostoka [in Russian].

Zolotarev, V.A. (Ed.) (2000). Rossiia (SSSR) v lokalnykh voinakh i voiennykh konfliktakh vtoroi poloviny $X X$ veka [Russia (USSR) in local wars and military conflicts of the second half of the twentieth century]. Moskva: Kuchkovo pole [in Russian].

\section{Andrei Pospelov}

(Odessa Academy of Continuing Education, Odessa, Ukraine)

ORCID: https://orcid.org/0000-0002-8789-6393

\section{Development of Iraqi Navy in 1958-1973 and Kuwait Crises}

The paper describes the peculiar features of formation and development of Iraqi Navy from the July Revolution of 1958 to the end of the second Kuwait crisis in February-March 1973. Details are given of all warships, motorboats and auxiliary vessels delivered to Iraq from the Soviet Union as the only supplier of naval equipment to the country at that time. It is indicated that the Republic of Iraq became the first among the Persian Gulf states to have in its disposal ships - carriers of missile weapons. The activities of some commanders of Iraqi Navy, especially, Syrian citizen Ali al-Dairi, in particular, his activities to create and develop a marine culture in the country, are briefly characterized. The events of potential British aggression against Iraq in 1958, the First Kuwait crisis of 1961 and the specific actions of Iraqi Navy during the Second Kuwait crisis of 1973 are described in detail.

Keywords: Iraq Republic, Navy, Kuwait crisis, combat motorboats, division 